\title{
BRIN \& ORGANISASI RISET AGAMA DAN KEAGAMAAN
}

\author{
Aji Sofanudin, Agus Fanar Syukri, Idham Khalid Bodi, Joko Tri Haryanto, \\ Agus Iswanto, Abu Muslim, Muh Subair, Wahab
}

Diterima: 10 Juli 2021, direviu: 11 Juli 2021, diterbitkan: 12 Juli 2021

\begin{abstract}
Abstrak:
Perpres Nomor 33 Tahun 2021 tentang Badan Riset dan Inovasi Nasional (BRIN) tidak secara eksplisit menyebutkan adanya nomenklatur agama dan keagamaan. Para peneliti di lingkungan Badan Litbang dan Diklat Kementerian Agama RI perlu mendapatkan kejelasan tentang desain "rumah baru"-nya dalam BRIN. Pembentukan Organisasi Riset (OR) Agama dan Keagamaan menjadi kebutuhan mendesak dalam kerangka menjamin eksistensi riset bidang agama dan keagamaan di Indonesia. Beberapa pemikiran alternatif nama Pusat Riset (PR) dalam Organisasi Riset Agama dan Keagamaan yang diusulkan, yaitu tiga, empat, lima, atau tiga belas PR.
\end{abstract}

Kata Kunci: BRIN; Organisasi Riset (OR); Pusat Riset (PR); Agama; Keagamaan; Pesantren

\section{A ISU KEBIJAKAN}

Presiden Jokowi mengonsolidasikan seluruh sumber daya riset dan inovasi nasional melalui Perpres Nomor 33 Tahun 2021 tentang Badan Riset dan Inovasi Nasional (BRIN) sebagai tindak lanjut dari Perpres Nomor 74 Tahun 2019, dengan payung kebijakan UU Nomor 11 Tahun 2019 tentang Sistem Nasional Ilmu Pengetahuan dan Teknologi. Namun demikian, kebijakan tersebut belum mengatur riset bidang agama (Sofanudin, 2021), setidaknya dengan merujuk Pasal 9 Perpres Nomor 33 Tahun 2021, yang tidak menyebutkan adanya kedeputian yang membidangi masalah agama dan/atau keagamaan.

\section{B ANALISIS}

Menurut (Pradana et al., 2021) ada banyak tantangan utama yang dihadapi Indonesia, di antaranya rendahnya kualitas institusi/kelembagaan. Untuk memperbaiki kualitas institusi/kelembagaan, harus dilaksanakan transformasi organisasi, termasuk di lembaga riset (Zuhro, 2020). Transformasi kelembagaan Badan Litbang dan Diklat Kementerian Agama RI ke dalam skema BRIN tentu menimbulkan beberapa persoalan. Salah satu persoalan yang muncul adalah masalah "rumah baru" beserta "penghuninya". Apa nama OR dan PR apa yang tepat, siapa saja para peneliti bidang keagamaan yang akan bermigrasi ke dalam OR dan PR tersebut.

Kepala BRIN dan Tim Transisi BRIN telah membuka peluang kemungkinan pembentukan Organisasi-Organisasi Riset (OR) dan Pusat-Pusat Riset (PR), termasuk di dalamnya wacana pembentukan OR Agama dan Keagamaan. Rekomendasi Temu Peneliti Nasional Agama, Badan Litbang dan Diklat Kementerian Agama RI, yang tergabung dalam Asosiasi Peneliti Agama Indonesia (APAI) 10-12 Juni 2021 di Serpong, Tangerang Selatan, Banten yll juga mendorong terbentuknya OR Agama dan Keagamaan dalam skema BRIN, meskipun dalam wacana temu peneliti juga menguat "cukup" dengan membentuk "PR Agama dan Keagamaan" atau "PR Agama dan Kepercayaan" sebagai bagian dari OR Sosial Humaniora yang diusulkan oleh Kedeputian Ilmu Pengetahuan Sosial dan Kemanusiaan (IPSK) LIPI.

Gagasan yang muncul terkait pembentukan PR-PR dalam OR Agama dan Keagamaan dalam BRIN meliputi tiga model: Model Pertama, kesamaan nama dengan nama OR-nya yaitu tiga pusat: (1) PR Agama, (2) PR Keagamaan, dan (3) PR Pendidikan Agama dan Keagamaan. PR agama mengkaji agama dalam kerangka teks, norma, ritus. Secara praktis, PR ini akan ditempati oleh para peneliti ex Lektur dan Lajnah. PR Keagamaan mengkaji agama sebagai fenomena sosial, sebagai fakta sosial. Secara praktis menjadi rumah ex peneliti bimas agama dan layanan keagamaan. PR Pendidikan Agama dan Keagamaan, mengkaji agama dalam bingkai pendidikan: pesantren, madrasah, serta pendidikan agama di sekolah.

Model kedua, merujuk pada ARKAN (Agenda Riset Keagamaan Nasional), yang terdiri atas 13 fokus yaitu: (1) kajiaan teks suci dalam agama-agama, (2) syariah, hukum dan peraturan perundang-undangan, (3) negara, agama, dan masyarakat, (4) keragaman dalam etnis, budaya, sosial, dan tradisi keagamaan, (5) studi Kawasan dan globalisasi, (6) tradisi pesantren dalam konteks masyarakat Indonesia, (7) pengembangan pendidikan, (8) sejarah, arkeologi dan manuskrip, (9) pengembangan ekonomi dan bisnis berbasis syariah, (10) Isu jender dan keadilan, (11) kesejahteraan sosial dalam masyarakat, (12) lingkungan dan pengembangan teknologi, (13) pengembangan kedokteran dan kesehatan, apabila dibentuk masing-masing 
sebagai PR, maka akan muncul 13 PR di OR yang diusulkan; tetapi modalitas SDM-nya akan kurang, sehingga dari 13 fokus kajian tersebut, sebenarnya dapat diperas menjadi 5 PR saja yaitu (1) PR Agama dan Kebangsaan, (2) PR Pendidikan Agaam dan Keagamaan, (3) Pusa Riset Agama dan Tantangan Kontemporer, (4) PR Kitab Suci, Literatur, dan Khazanah Keagamaan, (5) PR Kerukunan dan Moderasi Beragama, dengan modalitas SDM yang mencukupi.

Di luar itu, sebenarnya berkembang, aneka pemikiran nama PR-PR yang lain, antara lain: digitalisasi agama, agama dan tantangan global, agama dan jender, agama dan masyarakat serta ide-ide lain. Beberapa pemikiran lain yang muncul terkait isu-isu keagamaan strategis misalnya: isu pendidikan agama; isu moderasi beragama, isu beragama di era digital; isu agama lokal, minoritas, dan aliran kepercayaan; isu khazanah budaya, tradisi, dan manuskrip keagamaan; isu konflik, ekstremisme, radikalisme dan terorisme; isu pelayanan keagamaan; isu lingkungan hidup; isu gerakan sosial baru; isu populisme agama dan formalisasi agama; isu pemberdayaan ekonomi umat/jamaah; isu kesetaraan gender; isu perlindungan anak dan keadilan.

Model ketiga, Ada juga gagasan yang diusulkan oleh APAI, yaitu 4 PR: (1) PR Kerukunan dan Moderasi Beragama, (2) PR Pesantren, Pendidikan Agama dan Keagamaan, (3) PR Agama dan Peradaban, (4) PR Agama dan Kebijakan Publik; tetapi gagasan APAI ini, secara spesifik belum menyebutkan adanya home base.

Model keempat, Kembali kepada khittah. Model ini merujuk kepada klasifikasi kajian Badan Litbang Depag di awal lembaga ini ada. Secara umum, model ini pun masih dipakai saat ini terkait nama puslitbang di Badan Litbang dan Diklat Kementerian Agama RI. Kalau pun ada perbedaan, sekedar titik tekan aja, agar riset kementerian sesuai dengan Peraturan Menteri Agama Republik Indonesia Nomor 19/2019 Tentang Organisasi Dan Tata Kerja Instansi Vertikal Kementerian Agama (2019). Kondisi saat ini adalah Badan Litbang dan Diklat Kementerian Agama RI terdiri atas (1) Pusat Litbang Bimas Agama dan Layanan Keagamaan, (2) Pusat Litbang Pendidikan Agama dan Keagamaan, (3) Pusat Litbang Lektur, Khazanah Keagamaan, dan Manajemen Organisasi, (4) Pusdiklat Tenaga Administrasi, (5) Pusdiklat Tenaga Teknis Pendidikan dan Keagamaan, (6) Lajnah Pentashihan Mushaf Al-Quran.

Badan Litbang dan Diklat Kementerian Agama terdiri atas dua rumah: rumah litbang dan rumah diklat. Terkait dengan rumah yang selaras dengan fungsi Litbangjirap meliputi 3 Puslitbang yaitu (1) Pusat Litbang Bimas Agama dan Layanan Keagamaan, (2) Pusat Litbang Pendidikan Agama dan Keagamaan, (3) Pusat Litbang Lektur, Khazanah Keagamaan, dan Manajemen Organisasi. Nama puslitbang sekarang ini, lebih cenderung melekat kepada "struktur" di Kementerian Agama. Nomenklatur seperti "bimas", "layanan", "manajemen organisasi" dirasa kurang tepat terkait dengan kegiatan litbangjirap yang ada di UU 11/2019 tentang Sisnas Iptek.

Oleh karena itu, apabila dikembalikan kepada khittah, atau kondisi awal di mana area kajian Badan Litbang dan Diklat lebih bersifat substantif. PR yang diusulkan meliputi tiga rumah besar, yaitu: Kehidupan Beragama, Pendidikan Agama dan Keagamaan, serta Lektur dan Khazanah Keagamaan. Pendekatan yang digunakan adalah rumah, kamar, dan modalitas SDM. Rumah adalah kondisi saat ini kajian agama di masa awal, kamar adalah area kajian, dan modalitas SDM merupakan kondisi saat ini para peneliti di masingmasing satker yang berpeluang besar melakukan migrasi ke dalam BRIN.

Tabel 1. Pendekatan Rumah, Kamar, dan Potensi SDM Bidang Agama dan Keagamaan

\begin{tabular}{|c|l|l|l|}
\hline No & \multicolumn{1}{|c|}{ Rumah } & \multicolumn{1}{|c|}{ Kamar } & \multicolumn{1}{|c|}{ Modalitas SDM } \\
\hline 1 & Kehidupan Beragama & $\begin{array}{l}\text { (1) Aliran, Organisasi dan Gerakan Agama dan Kepercayaan, (2) } \\
\text { Kerukunan dan Hubungan Lintas Agama; (3) Pelayanan } \\
\text { Keagamaan; (4) Moderasi Beragama. }\end{array}$ & Bimas Agama \\
\hline 2 & $\begin{array}{l}\text { Pendidikan Agama } \\
\text { dan Keagamaan }\end{array}$ & $\begin{array}{l}\text { (1) Pesantren dan Pendidikan Keagamaan Lainnya; (2) } \\
\text { Madrasah; (3) Pendidikan Agama pada Sekolah }\end{array}$ & Pendidikan Agama \\
\hline 3 & $\begin{array}{l}\text { Lektur dan Khazanah } \\
\text { Keagamaan }\end{array}$ & $\begin{array}{l}\text { (1) Kitab Suci; (2) Literatur Keagamaan Klasik dan kontemporer; } \\
\text { (3) Seni dan Tradisi Keagamaan; (4) Sejarah Keagamaan; dan (5) } \\
\text { Arkeologi Keagamaan). }\end{array}$ & Lektur dan LPMQ \\
\hline
\end{tabular}

Berdasarkan kondisi saat ini, dari 4 model tersebut di atas, dipandang cukup membuat lima PR yaitu dengan cara membelah "rumah" Pusat Pendidikan Agama dan Keagamaan menjadi dua, yaitu "Pendidikan Agama" dan "Pendidikan Keagamaan". Cara pembelahan yang sama dilakukan oleh 
"lektur" dan "khazanah" dipisah. Dengan cara ini akan terbentuk setidaknya 5 PR di OR Agama dan Keagamaan, seperti ditunjukkan di Tabel 2, dan simulasi secara lebih terperinci terlampir di Tabel 4.

Tabel 2. Nama PR, Modalitas SDM Pejabat Fungsional dan Home Base (Kedudukan) yang diusulkan

\begin{tabular}{|c|l|c|l|c|}
\hline No & Nama Pusat-PR (PR) yang diusulkan & \multicolumn{1}{l|}{$\begin{array}{l}\text { Modalitas } \\
\text { SDM }\end{array}$} & Pejabat Fungsional & Kedudukan \\
\hline 1 & PR Kehidupan Beragama & 35 orang & Peneliti Agama & Jakarta \\
\hline 2 & PR Pendidikan Agama & 33 orang & Peneliti Agama & Jakarta \\
\hline 3 & PR Lektur Keagamaan & 35 orang & Peneliti Agama & Jakarta \\
\hline 4 & PR Pesantren dan Moderasi Beragama & 30 orang & Peneliti Agama & Semarang \\
\hline 5 & PR Khazanah Keagaman & 50 orang & $\begin{array}{l}\text { Peneliti Agama \& } \\
\text { Peneliti Soshum lain }\end{array}$ & Makassar \\
& & $(36+14)$ & & \\
\hline & Total & $\mathbf{1 8 3 * \text { orang }}$ & & \\
\hline
\end{tabular}

Keterangan: *Asumsi yang digunakan 100\% Peneliti Agama di Kementerian Agama (Kemenag) akan migrasi ke dalam BRIN, hasil pemetaan internal Kemenag yang dilaksanakan di tahun 2021, sebesar $76 \%$ peneliti siap migrasi ke BRIN dan $24 \%$ tetap di Kemenag.

Berdasarkan wacana yang ditawarkan oleh Kepala BRIN kepada Balitbang di K/L terkait transisi kelembagaan yang meliputi tiga opsi: (1) "bedol desa", (2) parsial, (3) program/anggaran; secara faktual, kasus di Kementerian Agama lebih tepat disebut "bedol dusun". Rumah Litbang saja yang kemudian bertransformasi ke BRIN, sementara rumah Diklat tetap di Kemenag. Untuk kemudahan dan kelancaran proses transformasi kelembagaan diperlukan "bedol dudun" di Semarang dan Makassar, yakni "ganti logo" untuk BLA Semarang dan BLA Makassar.

\section{SIMPULAN}

Berdasarkan uraian tersebut di atas, Policy Brief ini merekomendasikan urgensi pembentukan OR Agama dan Keagamaan dengan beberapa nama PR-nya, seperti yang ditunjukkan di Tabel 3 sebagai berikut:

Tabel 3. Alternatif Nama-Nama PR di OR Agama dan Keagamaan yang diusulkan

\begin{tabular}{|c|c|c|}
\hline No & Jumlah PR & Alternatif Nama-Nama PR \\
\hline \multirow[t]{2}{*}{1} & \multirow[t]{2}{*}{$3 \mathrm{PR}$} & (1) Agama, (2) Keagamaan, (3) Pendidikan Agama dan Keagamaan \\
\hline & & $\begin{array}{l}\text { (1) Kehidupan Beragama, (2) Pendidikan Agama dan Keagamaan, (3) Lektur dan Khazanah } \\
\text { Keagamaan }\end{array}$ \\
\hline 2 & $4 \mathrm{PR}$ & $\begin{array}{l}\text { (1) PR Kerukunan dan Moderasi Beragama, (2) PR Pesantren, Pendidikan Agama dan Keagamaan, } \\
\text { (3) PR Agama dan Peradaban, (4) PR Agama dan Kebijakan Publik }\end{array}$ \\
\hline 3 & $5 \mathrm{PR}$ & $\begin{array}{l}\text { (1) PR Kehidupan Keagamaan di Jakarta, (2) PR Pendidikan Agama di Jakarta, (3) PR Lektur } \\
\text { Keagamaan di Jakarta, (4) PR Pesantren dan Moderasi Beragama di Semarang, dan (5) PR Khazanah } \\
\text { Keagamaan di Makassar }\end{array}$ \\
\hline 4 & $13 \mathrm{PR}$ & $\begin{array}{l}\text { (1) kajiaan teks suci dalam agama-agama, (2) syariah, hukum dan peraturan perundang-undangan, (3) } \\
\text { negara, agama, dan masyarakat, (4) keragaman dalam etnis, budaya, sosial, dan tradisi keagamaan, (5) } \\
\text { studi Kawasan dan globalisasi, (6) tradisi pesantren dalam konteks masyarakat Indonesia, (7) } \\
\text { pengembangan pendidikan, (8) sejarah, arkeologi dan manuskrip, (9) pengembangan ekonomi dan } \\
\text { bisnis berbasis syariah, (10) Isu jender dan keadilan, (11) kesejahteraan sosial dalam masyarakat, (12) } \\
\text { lingkungan dan pengembangan teknologi, (13) pengembangan kedokteran dan kesehatan. }\end{array}$ \\
\hline
\end{tabular}

Melihat faktor sejarah, modalitas dan persebaran SDM Peneliti Agama di seluruh Indonesia, serta berdasarkan prioritas pembangunan nasional, usulan 5 PR dengan tiga bome base menjadi alternatif solusi yang terbaik OR Agama dan Keagamaan di lingkungan BRIN, dan terkait bome base PR di Semarang dan Makassar wacana "bedol desa" menjadi alternatif solusi terbaik. 


\section{REFERENSI}

Keputusan Menteri Agama Nomor 346 Tahun 2004 tentang Organisasi dan Tata Kerja Balai Penelitian dan Pengembangan Agama

Peraturan Menteri Agama Republik Indonesia nomor 19/2019 tentang Organisasi dan Tata Kerja Instansi Vertikal Kementerian Agama, Pub. L. No. PMA 19/2019, 1115 Kementerian Agama Republik Indonesia 619 (2019). https://peraturan.bpk.go.id/Home/Details/130631/peraturan-menag-no-19-tahun-2019

Pradana, A. W., Sevatita, A., Asmara, A. Y., Yusuf, A. A., Pantjadarma, D., Hidayat, D., Siregar, F., Rakhmani, I., Nugraha, L. K., Royono, R., \& Nugroho, Y. (2021). Cetak Biru Ekosistem Pengetahuan dan Inovasi. Ristek/BRIN BPPN KemenPANRB KSI.

Sofanudin, A. (2021, June 7). Urgensi Riset Agama. Tribun Jawa Tengah. https://jateng.tribunnews.com/2021/06/07/opiniaji-sofanudin-urgensi-riset-agama?page $=$ all

Tim APAI. (2021). Position Paper: OR Agama dan Keagamaan, Badan Riset dan Inovasi Nasional. Jakarta: Asosiasi Peneliti Agama Indoneisa

Undang-undang Nomor 18 Tahun 2019 tentang Pesantren

Zuhro, R. S. (2020). Reformasi Birokrasi di Lembaga Penelitian. 


\section{LAMPIRAN}

Tabel 4. Simulasi PR-PR di OR Agama dan Keagamaan yang diusulkan

\begin{tabular}{|c|c|c|c|c|c|c|}
\hline No & $\begin{array}{l}\text { Kondisi } \\
\text { Saat ini }\end{array}$ & & Bidang Kajian & Potensi SDM ${ }^{* *}$ & $\begin{array}{c}\text { Usulan Nama } \\
\text { PR (PR) }\end{array}$ & $\begin{array}{c}\text { Potensi Kedudukan } \\
\text { Kantor }\end{array}$ \\
\hline 1 & $\begin{array}{l}\text { Kehidupan } \\
\text { Beragama }\end{array}$ & 1 & $\begin{array}{l}\text { Aliran, Organisasi, } \\
\text { Gerakan Agama dan } \\
\text { Kepercayaan } \\
\text { Kerukunan dan } \\
\text { Hubungan Lintas } \\
\text { Agama } \\
\text { Pelayanan Keagamaan }\end{array}$ & $\begin{array}{l}\text { Pusat 1: } 26 \\
\text { CPNS: } 2 \\
\text { BLAJ bidang } \\
\text { bimas: } 7\end{array}$ & $\begin{array}{l}\text { Kehidupan } \\
\text { Beragama }\end{array}$ & $\begin{array}{l}\text { Jl Gatot Subroto (Gedung } \\
\text { LIPI Jakarta) }\end{array}$ \\
\hline 2 & $\begin{array}{l}\text { Pendidikan } \\
\text { Agama dan } \\
\text { Keagamaan }\end{array}$ & $\begin{array}{l}1 \\
2\end{array}$ & $\begin{array}{l}\text { Madrasah } \\
\text { Pendidikan Agama } \\
\text { pada Sekolah }\end{array}$ & $\begin{array}{l}\text { Pusat 2: } 22 \\
\text { CPNS: } 3 \\
\text { BLAJ bidang } \\
\text { pendidikan: } 8 \\
\end{array}$ & $\begin{array}{l}\text { Pendidikan } \\
\text { Agama }\end{array}$ & $\begin{array}{l}\text { Jl Gatot Subroto (Gedung } \\
\text { LIPI Jakarta) }\end{array}$ \\
\hline 3 & $\begin{array}{l}\text { Lektur dan } \\
\text { Khazanah } \\
\text { Keagamaan }\end{array}$ & $\begin{array}{l}1 \\
2\end{array}$ & $\begin{array}{l}\text { Kitab Suci } \\
\text { Literatur Keagamaan } \\
\text { Klasik dan kontem- } \\
\text { porer } \\
\text { Arkeologi Keagamaan }\end{array}$ & $\begin{array}{l}\text { Pusat } 3: 18 \\
\text { CPNS: } 2 \\
\text { LPMQ: } 8 \\
\text { BLAJ bidang } \\
\text { lektur: } 7\end{array}$ & $\begin{array}{l}\text { Lektur } \\
\text { Keagamaan }\end{array}$ & $\begin{array}{l}\text { Jl Gatot Subroto (Gedung } \\
\text { LIPI Jakarta) }\end{array}$ \\
\hline 4 & RPJMN & 1 & $\begin{array}{l}\text { Pesantren/Pendidikan } \\
\text { Keagamaan } \\
\text { Moderasi Beragama }\end{array}$ & $\begin{array}{l}\text { BLAS: } 23 \\
\text { CPNS: } 4 \\
\text { Peneliti Agama di } \\
\text { UIN Jogja: } 3\end{array}$ & $\begin{array}{l}\text { Pesantren dan } \\
\text { Moderasi } \\
\text { Beragama }\end{array}$ & $\begin{array}{l}\text { Beberapa alternatif: } \\
1 \text { Share office lantai } 1 \\
\text { Kemenag, lantai } 2 \text { brin, } \\
\text { lantai } 3 \text { bersama } \\
2 \text { Gedung lama BLAS, Jl } \\
\text { Pelem Kuweni } \\
3 \text { Gedung Lemlit UIN } \\
\text { Walisongo Semarang } \\
4 \text { Ex Gedung Pascasarjana } \\
\text { UNNES } \\
5 \text { Gedung Bappeda } \\
\text { Provinsi Jawa Tengah }\end{array}$ \\
\hline 5 & --- & 1 & $\begin{array}{l}\text { Seni dan Tradisi } \\
\text { Keagamaan } \\
\text { Sejarah Keagamaan }\end{array}$ & $\begin{array}{l}\text { BLAM: } 31 \\
\text { CPNS: } 4 \\
\text { Peneliti Agama di } \\
\text { Sorong: } 1 \\
\text { Peneliti Soshum } \\
\text { lain: } 14\end{array}$ & $\begin{array}{l}\text { Khazanah } \\
\text { Keagamaan }\end{array}$ & $\begin{array}{l}1 \text { Share office Gedung BLAM } \\
2 \text { Gedung UIN Makassar }\end{array}$ \\
\hline
\end{tabular}

Keterangan: **

Pusat 1: Pusat Litbang Bimas Agama dan Layanan Keagamaan (Jl Thamrin, Jakarta)

Pusat 2: Pusat Litbang Pendidikan Agama dan Keagamaan (J1 Thamrin, Jakarta)

Pusat 3: Pusat Litbang Lektur, Khazanah Keagamaan, dan Manajemen Organisasi (Jl Thamrin, , Jakarta)

LPMQ: Lajnah: Lajnah Pentashih Mushaf Al-Quran (TMII, Jakarta)

BLAJ: Balai Litbang Agama Jakarta (Cakung, Jakarta)

BLAS: Balai Litbang Agama Semarang (Ngaliyan, Semarang)

BLAM: Balai Litbang Agama Makassar (Makassar) 